\title{
МОДЕРНИЗАЦИЯ СИСТЕМЫ ГОСУДАРСТВЕННОЙ РЕГИСТРАЦИИ ПРАВ НА НЕДВИЖИМОЕ ИМУЩЕСТВО И СДЕЛОК С НИМ: ПРАКТИЧЕСКИЕ ВОПРОСЫ
}

\begin{abstract}
Аннотация: Автор анализирует состояние гражданского законодательства, регламентирующего государственную регистрацию прав на недвижимость, уделяя внимание практическим вопросам, возникающим в процессе его применения, и дает оценку имеющимся проблемам. В частности, сделан вывод, что некоторые новеллы правовых норм о регистрачии прав на недвижимость не имеют принципиального значения, поскольку наряду с государственной регистрацией прав могут осуществляться специальная регистрачия сделок или кадастровый учет отдельных видов недвижимого имущества (n. 2 cm. 131 ГК). Методом сравнительного анализа исследован вопрос о правомочиях сторон договора, хотя и не подлежащего регистрации, но обусловивщего возникновение, изменение или прекращение имущественных прав, для которых установлена государственная регистрация. В итоге, с момента подписания акта приема-передачи и до регистрации перехода права к покупателю, последний находится в статусе фактического владельиа недвижимости. Однако право собственности на указанный объект принадлежит продавиу. Такая правовая неопределенность влечет за собой необоснованные ограничения прав обеих сторон договора, скажем, в этот период наступил срок уплаты налога на имущество и продавеи, фактически уже не обладающий вещью, обязан заплатить налог до даты регистрации перехода прав. В то же время, покупатель, реально получивщий купленное имущество, не может распорядиться им в соответствии со своей волей и в своем интересе, поскольку у него отсутствует титул на данное имущество. Автор не соглашается с мнением законодателя о том, что термины - ограничение (обременение) прав синонимичны и предлагает сделать аутентичное толкование, в котором разъяснить, что под регистрацией обременений имеется в виду регистрация всех договоров с недвижимостью, по которым не происходит переход права собственности. Такое официальное разъяснение сняло бы все причины для смешения оснований регистрации сделок с недвижимым имуществом и прав на него.

Abstract: The author analyzes the civil legislation that regulates the state registration of real estate titles, concentrating on the practical questions arising in the process of its implementation, and gives an assessment to the current problems. Using the comparative analysis, the author examines the issue regarding the rights of both parties in a contract, which in itself does not qualify for registration, but stipulates changes to the property rights, for which there is a government registration. The author does not agree with the opinion of the legislation that the terms lien and encumbrance are not synonymous, and proposes that an amendment would be made to include authentic interpretation clarifying the registration of encumbrances includes registrations of all real estate contracts that do not involve transfer of ownership. Such official explanation would eliminate the legal limbo that carries unsubstantiated limitations to the rights of both sides of the contract. Ключевые слова: Недвижимость, регистрачия прав, обременения прав, ограничения прав, регистраиия сделок, переход права собственности, кадастровый учет, ЕГРП, оспаривание прав, недвижимое имушество.
\end{abstract}

Keywords: Real estate, title registration, encumbrance, lien, transaction registration, transfer of ownership, cadaster, contestation of ownership, property. 
DOI: 10.7256/1811-9018.2014.11.13092

При цитировании этой статьи сноска на dоі обязательна

\section{Право и политика $11(179) \cdot 2014$}

A нализируя изменения законодательства о регистрации прав на имущество и сделок с ним, можно прийти к выводу, что

- некоторые новелль правовых норм не имеют принципиального значения. Так, ст. 164 ГК и в прежней и ныне действующей редакции содержит правило о государственной регистрации сделок в случаях, предусмотренных законом, то есть наряду с государственной регистрацией прав могут осуществляться специальная регистрация сделок или кадастровый учет отдельных видов недвижимого имущества (п. 2 ст. 131 ГК). Для таких случаев диспозиция ст. 164 ГК в редакции Федерального закона от 07.05.2013 № 100-ФЗ устанавливает императивное, правило - правовые последствия сделки наступают после ее регистрации. Поскольку речь идет только о последствиях сделки, то возникает вопрос - является ли сама сделка действительной? Суды высшей инстанции исходят из того, что «сделка до ее регистрации не считается заключенной либо действительной в случаях, установленных законом» ${ }^{1}$, т.е. в случаях, НЕ установленных законом, сама сделка действительна.

Однако, имеющаяся судебная практика свидетельствует о другом: суды НЕ признают сделку заключенной либо действительной ДО ее регистрации. В подтверждение этого вывода сошлемся на кассационное определение Волгоградского областного суда от 20.04.2012 по делу № 33-3966/2012, которым в удовлетворении исковых требований о признании права собственности на жилой дом отказано. В обоснование своего мнения суд указал, что по закону сделка до ее регистрации не считается заключенной либо действительной ${ }^{2}$. Обзор опубликованных судебных дел показал, что действительность сделки, подлежащей регистрации, ВСЕГДА ставится в зависимость от факта ее регистрации.

В связи с этим возникает практический вопрос о правомочиях сторон договора, хотя и не подлежащего регистрации, но обусловившего возникновение, изменение или прекращение имущественных прав, для которых установлена государственная регистрация. Исходя из действующего порядка регистрации прав на имущество, можно совершенно обоснованно утверждать, что с момента заключения сделки и до момента регистрации имущественных прав по ней проходит довольно длительный период времени, в течение которого каждая сторона, заключившая сделку, вправе требовать

\footnotetext{
${ }^{1}$ П. 63 Постановления Пленума Верховного Суда РФ № 10, Пленума ВАС РФ № 22 от 29.04.2010 «О некоторых вопросах, возникающих в судебной практике при разрешении споров, связанных с защитой права собственности и других вещных прав».

2 [электрон. ресурс] // Консультант Плюс
}

от другой стороны исполнения своих обязанностей, скажем, покупатель, несмотря на отсутствие у него права собственности на предмет сделки, может потребовать от продавца передать ему объект недвижимости. После подписания акта приема-передачи и до регистрации перехода права на имущество от продавца к покупателю, последний находится в статусе фактического владельца объекта недвижимости. Однако право собственности на указанный объект принадлежит продавиу.

С нашей точки зрения, такая правовая неопределенность влечет за собой необоснованные ограничения прав обеих сторон договора, скажем, в этот период наступил срок уплаты налога на имущество и продавец, фактически уже не обладающий вещью, обязан заплатить налог до даты регистрации перехода прав. В то же время, покупатель, реально получивший купленное имущество, не может распорядиться им в соответствии со своей волей и в своем интересе, поскольку у него отсутствует титул на данное имущество. Этот вывод подтверждается мнением ученых и практиков, которые исходят из того, что в таких сделках следует охранять интересы третьих лиц (прежде всего кредиторов продавца), рассчитывающих на удовлетворение своих требований за счет недвижимого имущества продавца ${ }^{3}$. Что же касается ограничения прав сторон договора по распоряжению имуществом, то их следует признать объективно обоснованными, поскольку в противном случае неизбежны нарушения.

- Следующим актуальным вопросом государственной регистрации прав на имущество являются ограничения (обременения) прав, которые установлены в целях охраны и защиты публичных интересов.

Прежде всего, определим дефиниции используемых терминов - ограничения (обременения) прав. По мнению законодателя, эти понятия синонимичны, поэтому он употребляет их одновременно и дает общее определение - наличие установленных законом или уполномоченными органами в предусмотренном законом порядке условий, запрещений, стесняющих правообладателя при осуществлении права собственности либо иных вещных прав на конкретный объект недвижимого имущества (сервитута, ипотеки, доверительного управления, аренды, концессионного соглашения, ареста имущества и других) - ст. 1 Закона о регистрации прав на недвижимость.

Мы не разделяем такое толкование этих важнейших правовых категорий, поскольку цивилисты нескольких

\footnotetext{
${ }^{3}$ Подробнее см.: Брагинский М.И., Витрянский В.В. Договорное право. Кн. вторая: договоры о передаче имущества. М., 2003. С. 215.
} 
поколений, изучая данное правовое явление, смогли найти принципиальные различия между ограничением прав и их обременением. Так, В.П. Грибанов совершенно справедливо писал, что обременение - это чужое субъективное право на мою вещь со свойством следования. В то время как ограничение не следует за вещью, но при этом отличается от естественных границ, пределов субъективного права. Отсюда вполне логично сделать вывод, что правило о регистрации аренды как обременения - в действительности правило о регистрации именно права, а не сделки. Это мнение соответствует признаваемой многими отечественными цивилистами точке зрения - аренда ограничивает (обременяет) права собственника имущества. Кстати, на практике регистрации подлежал договор, на котором ставился штамп, а запись вносилась в раздел ЕГРП об обременениях прав.

Для устранения подобных коллизий целесообразно дать аутентичное толкование, в котором разъяснить, что под регистрацией обременений имеется в виду регистрация всех договоров с недвижимостью, по которым не происходит переход права собственности. Такое официальное разъяснение сняло бы все причины для смешения оснований регистрации сделок с недвижимым имуществом и прав на него.

Здесь уместно отметить, что тема регистрации сделок как обременений на самом деле не нова. Вспомним дискуссию с изменениями ст. 11 Закона об ипотеке, вызванную желанием банков иметь в ЕГРП знак обеспечения еще до выдачи кредита. В итоге было принято решение: в момент регистрации договора ипотеки вносится запись об обременении, а после фактической выдачи денег - регистрируется право залога. Получалось, что регистрировался договор (сделка), запись вносилась в раздел об обременениях, а потом регистрировались в разделе о правах сами права залогодержателя (ипотека). Таким образом, ипотека как обременение имущества, заложенного по договору об ипотеке, или при ипотеке, возникающей в силу закона, возникает с момента государственной регистрации ипотеки. При этом права залогодержателя (право залога) на имущество считаются возникшими с момента внесения записи об ипотеке в ЕГРП на недвижимое имущество и сделок с ним, если иное не установлено федеральным законом. Если обязательство, обеспечиваемое ипотекой, возникло после внесения в ЕГРП записи об ипотеке, то залогодержатель приобретает права с момента возникновения этого обязательства.

Гражданский оборот в условиях рынка расширяет способы и условия использования чужого имущества, обременяя тем самым права собственников и иных владельцев, которые нуждаются в соответствующих государственных гарантиях. К примеру, новая редакция параграфа 3 «Залог» главы 23 ГК (см. Федеральный закон от 31 декабря 2013 г. № 367-Ф3) регламентирует не только новые виды залога, но и предусматривает новые способы его учета. Так, в соответствии со ст. 339.1. ГК залог некоторых видов имущества, не относящегося к недвижимым вещам, может быть учтен путем регистрации уведомлений о залоге, поступивших от залогодателя, залогодержателя или в случаях, установленных законодательством о нотариате, от другого лица, в реестре уведомлений о залоге движимого имуществва, который ведется в порядке, установленном законодательством о нотариате. Совершенно очевидно, лицам, использующим эти новеллы законодательства, следует обеспечить дополнительные юридические гарантии.

- Однако анализ внесенных изменений и дополнений свидетельствует - «ситуация складывается с точностью до наоборот»: государство фактически не несет никакой ответственности за достоверность, своевременность и полноту записей, которые совершаются в различных реестрах регистрации прав и обременений на них. Например, п. 9 ст. $8^{1}$ ГК содержит перечень случаев причинения по вине органа, осуществляющего государственную регистрацию прав на имущество, убытков и возлагает расходы по их возмещению на счет казны Российской Федерации, а именно, убытки должны быть причинены:

- незаконным отказом в регистрации прав на имущество,

- уклонением от регистрации,

- внесением в госреестр незаконных или недостоверных данных о праве,

- нарушением порядка государственной регистрации прав на имущество.

Несомненно, эта норма имеет важное значение с точки зрения охраны прав и законных интересов субъектов гражданского оборота. Однако, если соотнести п. 9 ст. $8^{1}$ ГК со статьей 16 ГК, диспозиция которой охватывает любые случаи причинения убытков указанными органами, то можно сделать вывод: Федеральный закон от 30 декабря 2012 г. № 302-Ф3 сужает ответственность государственного регистрационного органа.

В то же время статья $16^{1}$ ГК содержит общую норму, устанавливающую ответственность государственных органов, органов местного самоуправления или должностных лиц указанных органов за ущерб, причиненный правомерными действиями этих органов или их должностных лиц. 
DOI: $10.7256 / 1811-9018.2014 .11 .13092$

При цитировании этой статьи сноска на dоі обязательна

\section{Право и политика 11 (179) • 2014}

- С нашей точки зрения, отсутствие корреляции между упомянутыми нормами свидетельствует о необходимости возобновления работы над Федеральным законом «О государственной регистрации прав на имущество» и принятия его в самое ближайшее время. При этом нормы ГК об ответственности государственных и муниципальных органов, в т.ч. госрегистрации, должны быть приведены в соответствие с ним. Уместно также вспомнить, что Административный регламент исполнения государственной функции по государственной регистрации прав на недвижимое имущество и сделок с ним 2006 г., признан утратившим силу Приказом Минюста РФ от 16 сентября 2010 г. № 227. Новый регламент еще не принят.

Таким образом, Российская Федерация, являясь конституиионным гарантом прав и свобод каждого члена намего общества, ослабила свою ответственность за нарушения в сфере регистрации прав и обременений на них.

Между тем система Торренса и системы стран Европы регистрации прав предоставляют любому лицу, пострадавшему из-за внесения в реестр записи, не соответствующей действительности, право требовать от государства компенсации в размере рыночной стоимости недвижимости даже при отсутствии вины. Отечественное законодательство не имеет таких положений. Поэтому те граждане, которые лишились недвижимости из-за нарушений регистрации прав, приходят в суд и просят вернуть недвижимость, так как им никто не компенсирует возникшие убытки. В итоге суд принимает решение - вернуть недвижимость, поскольку несправедливо не отнять у того, кому это не принадлежит. Эти предпосылки, несмотря на модернизацию законодательства, направленную на усиление защиты прав и интересов участников имущественных отношений, не поменялись. Более того, как отмечено выше, государство сузило свою ответственность, введя принцип ответственности при наличии вины. Теперь та компенсация, которая предусмотрена при утрате права на квартиру в размере 1 млн. рублей (жалкая компенсация), может быть взыскана только при наличии вины.

Иными словами, мотивы, на которых строилась существующая практика, не поменялись. С учетом этого следует признать, что принцип достоверности Реестра продекларирован новым законом, но реально не введен, поскольку система ответственности за его нарушение не только не изменилась, но и ухудшилась.

- Возвращаясь к проблемам регистрации прав на имущество, отметим, государственная регистрация перехода права на объект недвижимого имущества, его ограничения (обременения) или сделки с таким объектом осуществляется при условии наличия государственной регистрации ранее возникших прав на данный объект в ЕГРП. Несомненно, эти нововведения приняты с целью создать формальную регистрационную систему, одним из основных принципов которой является прозрачность деятельности субъектов гражданского оборота. При этом должны быть соблюдены установленные законом пределы открываемых сведений.

Однако при регистрации сделок конфиденциальная информация, то есть находящаяся за пределами установленного законом открытого перечня сведений, неизбежно становится известной третьим лицам. Думаем, что именно по этой причине экономически развитые страны мира регистрируют только объекты гражданских правоотношений и субъективные права на них. С нашей точки зрения, это разумное решение и упомянутый Федеральный закон от 30 декабря 2012 г. № 302 свидетельствует, что Россия присоединилась международному сообществу.

С учетом изложенного, вполне логично, что из п. 1 ст. 165 ГК исключены императивные нормы о ничтожности сделок, если при их совершении не были соблюдены требования закона о нотариальной форме и/или государственной регистрации. Согласно новой редакции п. 1 ст. 165 ГК суд уполномочен признать такую сделку действительной при условии, что одна из сторон полностью или частично исполнила эту сделку.

Эти нормы применимы ко всем сделкам, совершаемым в рамках гражданского законодательства, поскольку они находятся в Разделе I «Общие положения». Однако зададимся вопросом, у нас есть часть четвертая $Г К$, которая регулирует специальные правоотношения, и конкретно ст. 1232, предусматривающая регистрацию результатов интеллектуальной деятельности и средств индивидуализации, прав на них, а также договоров, заключаемых по их поводу.

Изменения данной статьи, внесенные Федеральным законом от 12 марта 2014 г. № 35-ФЗ ГК, полагаем, обусловлены теми же самими причинами, которые уже реализованы в части первой ГК применительно к сделкам вообще.

- Что же касается ситуаций с «несостоявшимся переходом права», «несостоявшимся залогом» и «несостоявшемся предоставлением», то, сравнив первоначальную редакцию п. 6 ст. 1232 ГК с ее новой диспозицией, можно сказать, что понятие о несостоявшемся юридически значимом действии не является новеллой. На наш взгляд, ничего нового в этом термине нет. Да, поменялось основание для наступления такого право- 
вого последствия: было - «несоблюдение требования о государственной регистрации договора», стало - «несоблюдение требования о государственной регистрации перехода исключительного права».

Правда, первоначальная диспозиция п. 6 ст. 1232 ГК предусматривала еще одно правовое последствие - недействительность соответствующего договора. В новой редакции этой статьи законодатель относится к договору индифферентно, оставляя его судьбу на усмотрение сторон.

Вместе с тем, следует иметь в виду, что в ряде других статей изменениями предусмотрено не только прямое указание на письменную форму сделки, но и последствия ее несоблюдения. Так, п. 2 ст. 1234 ГК гласит: договор об отчуждении исключительного права заключается в письменной форме. Несоблюдение письменной формы влечет недействительность договора. Эти нормы неоднократно повторяются в ГК, к примеру, вспомним статью 1369 ГК, которая касается договоров о распоряжении исключительным правом на изобретение, полезную модель или промышленный образец. Здесь также предусмотрено последствие - несоблюдение письменной формы влечет недействительность договора.

С такой позицией законодателя вполне можно согласиться. На самом деле, договор может полностью соответствовать нормам действующего законодательства и юридические основания признать его недействительным, формально, отсутствуют, в таких случаях одна из сторон, частично или полностью исполнившая свои обязательства по сделке, вправе обратиться в суд за защитой своих нарушенных прав, если другая сторона уклоняется от регистрации последствий заключенного договора, к примеру, перехода исключительных прав или их залога. При отсутствии письменной формы договора защитить такое право не представляется возможным.

Обратим внимание, игнорирование одной или обеими сторонами императивного требования закона о регистрачии перехода исключительных прав, либо об их залоге, а также о предоставлении права использования результата интеллектуальной деятельности или приравненного к нему средства индивидуализации влечет за собой совершенно обоснованное последствие-переход прав, их залог или предоставление права использования признаются несостоявшимся. Договор в этом случае утрачивает свою юридическую значимость.

Руководствуясь данными нормами, можно смоделировать ситуацию: аффилированные лица заключили лицензионный договор на передачу прав по неисключи- тельной лицензии и не зарегистрировали предоставление права пользования, однако реально его исполнили, то есть лицензиар получил вознаграждение за передачу прав, а лицензиат фактически стал выпускать свою продукцию под товарным знаком лицензиара. С точки зрения Федерального закона от 12 марта 2014 г. № 35ФЗ ГК правовые последствия такой сделки следующие:

а) юридические основания для признания лицензионного договора недействительным отсутствуют;

б) переход прав следует признать несостоявшимся;

в) суд обладает полномочиями признать договор действительным, а стороны могут осуществить регистрацию передачи прав на основании судебного решения.

- Вместе с тем, с принятием ст. $8^{1}$ ГК судебная практика не изменится, поскольку не изменилась основная посылка, если регистратор внес запись в Реестр, то можно обращаться в суд по поводу прав на имущество. При этом информация (отметка) о судебном разбирательстве по поводу зарегистрированного права в Реестре может отсутствовать.

- Особо внимания заслуживает договор аренды, поскольку в отношении его была довольно активная дискуссия, касающаяся вопроса правовых последствий несоблюдения условия о регистрации. В целях обеспечения единообразных подходов к разрешению этого вопроса Пленум Высшего Арбитражного Суда Российской Федерации принял Постановление от 25 декабря 2013 г. № 98 «О внесении дополнения в постановление Пленума Высшего Арбитражного Суда Российской Федерации от 17.11.2011 № 73 «Об отдельных вопросах практики применения правил Гражданского кодекса Российской Федерации о договоре аренды», в котором разъяснил: если стороны достигли соглашения в требуемой форме по всем существенным условиям договора аренды, который согласно пункту 2 статьи 609 ГК подлежит государственной регистрации, и не зарегистрировали его, то при рассмотрении споров между ними судам надлежит исходить из следующего: если собственник передал имущество в пользование, а другое лицо приняло его без каких-либо замечаний, соглашение о размере платы за пользование имуществом и по иным условиям пользования было достигнуто сторонами и исполнялось ими, то в таком случае следует иметь в виду, что оно связало их обязательством, которое не может быть произвольно изменено одной из сторон (статья 310 ГК), и оснований для применения судом положений статей 1102, 1105 ГК не имеется. В силу статьи 309 ГК пользование имуществом должно осуществляться и оплачиваться в соответствии с принятыми 
DOI: $10.7256 / 1811-9018.2014 .11 .13092$

При цитировании этой статьи сноска на доі обязательна

\section{Право и политика $11(179) \cdot 2014$}

на себя стороной такого соглашения обязательствами. Если названным соглашением установлена неустойка за нарушение условий пользования имуществом, она подлежит взысканию с должника.

В то же время в силу статьи 308 ГК права, предоставленные лицу, пользующемуся имуществом по договору аренды, не прошедшему государственную регистрацию, не могут быть противопоставлены им третьим лицам. В частности, такое лицо не имеет преимущественного права на заключение договора на новый срок (пункт 1 статьи 621 ГК), а к отношениям пользователя и третьего лица, приобретшего на основании договора переданную в пользование недвижимую вещь, не применяется пункт 1 статьи 617 ГК.

- Актуально мнение суда о том, что признанием зарегистрированного права отсутствующим не восстанавливаются права невладеющего собственника. Основанием для такого вывода послужило дело, рассмотренное Федеральным арбитражным судом Западно-Сибирского округа (Постановление от 2 октября 2013 г. № Ф04-4652/13 по делу № А27-18951/2012), суть которого сводилась к следующему:

ОАО «РУСАЛ» обратилось в Арбитражный суд Кемеровской области с иском к ООО «Алатау» о признании зарегистрированного права собственности на нежилое здание отсутствующим.

Как следует из материалов дела, 03.06.2003 г. за ОАО «РУСАЛ» зарегистрировано право собственности на отдельно стоящее здание (гараж на 30 машин) на земельном участке с кадастровым номером 42:13:0122002:0008, литера А. Основанием для регистрации указанного права собственности послужил дубликат плана приватизации ПО «Ачинский глинозёмный комбинат», утверждённый компетентным органом 19.04.1994.

21.04.2008г. за ООО «Алатау» зарегистрировано право собственности на нежилое здание (гараж № 3), на земельном участке с кадастровым номером 42:13:0122002:0008. В качестве основания для регистрации был представлен договор купли - продажи от 25.03.2008, заключённый с Ивановой Л.М.

ОАО «РУСАЛ», посчитав, что ООО «Алатау» незаконно занимает принадлежащее ему здание гаража, обратилось с указанным иском.

Суды первой и апелляционной инстанций, отказали в удовлетворении исковых требований, основываясь на недоказанности идентичности зарегистрированных за сторонами объектов недвижимости, а также порочности договора купли-продажи и несения ОАО «РУСАЛ» правомочий собственника в отношении спорного имущества.
Суд кассационной инстанции согласился с выводами судов первой и апелляционной инстанций и указал, что на основании п.1 ст. 131 ГК РФ право собственности, а также другие вещные права на недвижимость, в том числе их ограничение или возникновение, переход или прекращение подлежат государственной регистрации в ЕГРП.

В то же время согласно разъяснениям Пленумов ВС РФ и ВАС РФ от 29.04.2010 № 10/22 «О некоторых вопросах, возникающих в судебной практике при разрешении споров, связанных с защитой права собственности и других вещных прав», оспаривание зарегистрированного права на недвижимое имущество осуществляется путём предъявления исков, решения по которым являются основанием для внесения записи в ЕГРП.

Когда запись в ЕГРП нарушает право истца, которое не может быть защищено путём признания права или истребования имущества из чужого незаконного владения (право собственности на один и тот же объект недвижимости зарегистрировано за разными лицами, право собственности на движимое имущество зарегистрировано как на недвижимость, ипотека или иное обременение прекратились), оспаривание зарегистрированного права или обременения может быть осуществлено путём предъявления иска о признании права или обременения отсутствующими.

Из указанных выше разъяснений следует, что ㅁ первую очередь заявленные требования должны быть направлены на восстановление законных прав истца, поскольку с признанием зарегистрированного права отсутствующим не восстанавливаются права невладеющего собственника.

Как следует из материалов вышеуказанного дела, суды установили, что ОАО «РУСАЛ» фактически не владеет зданием гаража, поскольку не смогло представить доказательств его фактического нахождения в здании, а также несения бремени собственника.

Несмотря на указанные факты, ОАО «РУСАЛ « не заявило требований об оспаривании договора куплипродажи, который послужил основанием регистрации права собственности ООО «Алатау» на спорное имущество, то есть не оспорено право собственности ответчика. Также одновременно с требованием о признании зарегистрированного права отсутствующим не подан иск об истребовании имущества из чужого незаконного владения.

При указанных обстоятельствах суд кассационной инстанции признал отказ в удовлетворении исковых требований ОАО «РУСАЛ» правомерным. По нашему мнению, оснований для оспаривания этого решения нет. 
- Для лиц, осуществляющих свою обязанность по регистрации прав на имущество, актуально знать, что исполнение государственной функиии по регистрации прав включает в себя и такие административные процедуры, как:

- приостановление государственной регистрации прав (ст. 19 Закона о регистрации прав на недвижимость);

- отказ в государственной регистрации прав (ст. 20 Закона о регистрации прав на недвижимость).

$\mathrm{B}$ соответствии с диспозицией п. 1 ст. 19 Закона о регистрации прав на недвижимость государственная регистрация прав приостанавливается государственным регистратором при возникновении у него сомнений в:

- наличии оснований для государственной регистрации прав,

- подлинности представленных документов или достоверности указанных в них сведений;

- в случае непредставления документов (сведений, содержащихся в них), запрашиваемых органом, осуществляющим государственную регистрацию прав, по межведомственным запросам.

При этом на государственного регистратора возлагается обязанность принять необходимые меры по получению дополнительных документов и (или) сведений и (или) подтверждению подлинности документов, достоверности указанных в них сведений.

В день принятия решения о приостановлении государственной регистрации прав государственный регистратор обязан подготовить в письменное уведомление о приостановлении государственной регистрации прав, а также указать основания принятия такого решения и выдать или направить его заявителю (заявителям) в установленном порядке.

Государственная регистрация прав на земельный участок приостанавливается также в случае, если в государственном кадастре недвижимости в отношении такого земельного участка отсутствуют сведения о координатах характерных точек границ такого земельного участка или одна из границ такого земельного участка пересекает одну из границ другого земельного участка в соответствии с внесенными в государственный кадастр недвижимости сведениями о последнем. Из этого общего правила есть исключения, установленные законом (см., например, п. 1 ст. 19 Закона о регистрации прав на недвижимость).

Государственная регистрация сделки с объектом недвижимого имущества и (или) перехода, ограничения (обременения) права на ее основании на указанный объект приостанавливается при наличии ранее поданных документов на государственную регистрацию сделки с данным объектом недвижимого имущества и (или) перехода, ограничения (обременения) права на данный объект, по которым решение о государственной регистрации или об отказе в государственной регистрации не принято.

Государственная регистрация в этом случае приостанавливается до завершения государственной регистрации сделки с данным объектом недвижимого имущества и (или) перехода, ограничения (обременения) права на данный объект недвижимого имущества по ранее принятым документам.

При этом уведомление о приостановлении государственной регистрации прав на такой земельный участок также должно содержать рекомендации по устранению причин этого приостановления и к указанному уведомлению должна быть приложена кадастровая выписка о таком земельном участке, содержащая имеющиеся общедоступные кадастровые сведения о нем.

Государственная регистрация прав на основании судебного акта может приостанавливаться государственным регистратором при возникновении у него сомнений в подлинности представленных документов, а также при наличии предусмотренных законом оснований.

По вышеуказанным основаниям государственная регистрация прав может быть приостановлена не более чем на один месяц. Если в течение этого периода не будут устранены причины, препятствующие государственной регистрации прав, то государственный регистратор обязан отказать заявителю в государственной регистрации прав и сделать об этом соответствующую запись в книге учета документов.

Если инициатива приостановления государственной регистрации принадлежит правообладателю или иным управомоченным лицам (в регистрирующий орган поступило от них письменное заявление), то регистрация может быть приостановлена не более чем на три месяца. При этом в заявлении должны быть указаны причины, послужившие основанием для приостановления государственной регистрации прав, и срок приостановления. По другим основаниям (например, по решению суда) государственная регистрация может быть приостановлена на иные сроки.

- Основания и порядок отказа в государственной регистрации прав регламентирован статьей 20 Закона о регистрации прав на недвижимость, содержащей закрытый перечень обстоятельств, при которых регистрирующий орган может принять решение об отказе в регистрации. Так, может быть отказано в случаях, если:

- право на объект недвижимого имущества, о государственной регистрации которого просит заявитель, 
DOI: 10.7256/1811-9018.2014.11.13092

При цитировании этой статьи сноска на доі обязательна

\section{Право и политика $11(179) \cdot 2014$}

не является правом, подлежащим государственной регистрации прав в соответствии нормами действующего закона;

- с заявлением о государственной регистрации прав обратилось ненадлежащее лицо;

- документы, представленные на государственную регистрацию прав, по форме или содержанию не соответствуют требованиям действующего законодательства;

- акт государственного органа или акт органа местного самоуправления о предоставлении прав на недвижимое имущество признан недействительным с момента его издания в соответствии с законодательством, действовавшим в месте его издания на момент издания;

- лицо, выдавшее правоустанавливающий документ, не уполномочено распоряжаться правом на данный объект недвижимого имущества;

- лицо, которое имеет права, ограниченные определенными условиями, составило документ без указания этих условий;

- правоустанавливающий документ об объекте недвижимого имущества свидетельствует об отсутствии у заявителя прав на данный объект недвижимого имущества;

- правообладатель не представил заявление и иные необходимые документы на государственную регистрацию ранее возникшего права на объект недвижимого имущества, наличие которых необходимо для государственной регистрации возникших после введения в действие настоящего Федерального закона перехода данного права, его ограничения (обременения) или совершенной после введения в действие настоящего Федерального закона сделки с объектом недвижимого имущества, в случаях, если обязанность по представлению таких документов возложена на заявителя;

- не представлены документы, необходимые в соответствии с настоящим Федеральным законом для государственной регистрации прав, в случаях, если обязанность по представлению таких документов возложена на заявителя;

- имеются противоречия между заявленными правами и уже зарегистрированными правами;

- осуществление государственной регистрации права собственности не допускается в иных прямо установленных законом случаях;

- ответ органа государственной власти или органа местного самоуправления на межведомственный запрос свидетельствует об отсутствии документа и (или) информации, необходимых для государственной регистрации прав, если соответствующий документ не представлен заявителем по собственной инициативе;
- в государственном кадастре недвижимости в отношении земельного участка, на государственную регистрацию прав на который представлены документы, отсутствуют сведения о координатах характерных точек границ такого земельного участка или одна из границ такого земельного участка пересекает одну из границ другого земельного участка в соответствии с внесенными в государственный кадастр недвижимости сведениями о последнем, за исключением случаев, установленных в законе.

- Обратим внимание, наличие судебного спора о границах земельного участка не является основанием для отказа в государственной регистрации прав на него. Таким образом, данный пункт ещзе раз подчеркнул отсутствие правовой связи между судебным спором о праве и реально существующими записями о таком праве в ЕГРП.

При принятии решения об отказе в государственной регистрации прав заявителю направляется по указанному в заявлении о государственной регистрации прав или в требовании судебного пристава-исполнителя адресу сообщение о причинах отказа. При этом делается обязательная ссылка на положения нормы закона, послужившие основанием для принятия такого решения. Сообщение направляется в срок не более чем пять дней после окончания срока, установленного для рассмотрения заявления.

Если одновременно с сообщением об отказе в государственной регистрации прав заявителю должны быть направлены представленные заявителем документы, в том числе подлинники. Сообщение об отказе в государственной регистрации прав и указанные документы по желанию заявителя могут быть выданы ему лично.

При отказе в государственной регистрации права уплаченная государственная пошлина за государственную регистрацию права не возвращается. При прекращении государственной регистрации прав на основании соответствующих заявлений сторон договора возвращается половина суммы, уплаченной в виде государственной пошлины.

Если отказ в государственной регистрации прав признан судом необоснованным (не соответствующим основаниям, указанным в настоящем Федеральном законе) и в решении суда указано на необходимость осуществить государственную регистрацию прав, она осуществляется без заявления о государственной регистрации прав на основании соответствующего решения суда, вступившего в законную силу и поступившего в орган, осуществляющий государственную регистрацию прав, и документов, ранее помещенных 
DOI: 10.7256/1811-9018.2014.11.13092

При цитировании этой статьи сноска на dоі обязательна

Юридический практикум

в дело правоустанавливающих документов. В течение трех рабочих дней со дня поступления такого решения суда государственный регистратор обязан уведомить заявителя по указанному в заявлении о государственной регистрации прав адресу о поступлении такого решения суда и сроке окончания осуществления государственной регистрации прав.

- Отказ в государственной регистрации прав может быть обжалован заинтересованным лицом в суд. Казалось бы все ясно и понятно. Однако, практика свидетельствует, что довольно часто работки регистрирующих органов усматривают в решениях судов ошибки и не выполняют их. В результате Президиума ВАС РФ вынужден был издать Информационное письмо от 21.07.2009 № 132 «О некоторых вопросах применения арбитражными судами статей 20 и 28 Федерального закона «О государственной регистрации прав на недвижимое имущество и сделок с ним», в котором разъяснил:

- вступившие в законную силу судебные акты являются обязательными для всех органов, организаций, должностных лиц и граждан и поэтому подлежат исполнению на всей территории РФ;

- регистратор не вправе давать правовую оценку вступившему в законную силу судебному акту, а также осуществлять переоценку обстоятельств дела и доказательств, на которых основан вступивший в за- конную силу судебный акт. Отказ в государственной регистрации права в этом случае является незаконным.

Кроме того Президиум ВАС РФ указал, если представленная заявителем копия судебного акта не соответствует установленным требованиям (не содержит отметку о вступлении его в законную силу либо не заверена гербовой печатью суда, либо представлена в меньшем количестве экземпляров), то регистратор вправе приостановить государственную регистрацию прав и предложить заявителю устранить нарушение. Если в течение одного месяца заявитель не устранит недостатки, то на основании абзаца десятого пункта 1 статьи 20 Закона о регистрации прав на недвижимость регистратор принимает решение об отказе в государственной регистрации права.

Однако это Информационное письмо Президиума ВАС РФ не дало ожидаемого эффекта, поэтому Росреестр также опубликовал Письмо от 01.06.2010 № 14-20-1831-1/10 «О приостановления государственной регистрации прав на недвижимое имущество и сделок с ним», в котором наряду с теоретическими вопросами разъяснения оснований приостановления государственной регистрации прав указал, что в рамках установленной компетенции ни он, ни его территориальные органы не вправе принимать решения о наложении ареста, пересматривать и отменять судебные решения.

\section{Библиография:}

1. Гражданский кодекс Российской Федерации от 26 января 1996 г. N 14-Ф3 // Собрание законодательства Российской Федерации от 29 января 1996 г. N 5 ст. 410 (с изм. и доп., вступ. в силу с 01.09.2014)

2. Федеральный закон от 30.12.2012 № 302-Ф3 «О внесении изменений в главы 1, 2, 3 и 4 части первой Гражданского кодекса Российской Федерации» // http://pravo.fso.gov.ru/ips/, 04.03.2013;

3. Федеральный закон от 21.07.1997 N 122-Ф3 «О государственной регистрации прав на недвижимое имущество и сделок с ним» // http://www.pravo.gov.ru, 22.07.2014.

4. Алексеев В.А. Недвижимое имущество: правовой режим и государственная регистрация прав // Дисс. ... доктора юридических наук. М. 2008.

5. Бабкин С.А. Основные начала организации оборота недвижимости.

6. Базанов И.А. Происхождение современной ипотеки. Новейшие течения в вотчинном праве в связи с современным строем народного хозяйства. М., 2004

7. Бевзенко Р.С. Государственная регистрация прав на недвижимое имущество: проблемы и пути решения., М. 2011

8. Брагинский М.И., Витрянский В.В. Договорное право. Кн. вторая: договоры о передаче имущества. М., 2003

9. Демушкина Е.С. Проблемы применимости акцессорности и вещной защиты ипотеки в российском гражданском праве. «Юриспруденция», 2011.

10. Дискин Е.И. Государственная регистрация прав на недвижимое имущество на основании судебных актов // Автореф. дисс. . . канд. юрид. наук. .М. 2013.

11. Карибов К., Чайковская О. Отмена государственной регистрации договоров аренды недвижимого имущества // Слияния и поглощения. № 3. 2013.

12. Киндеева Е.А., Пискунова М.Г. Недвижимость: права и сделки. Кадастровый учет и государственная регистрация прав. M., 2011

13. Концепция развития гражданского законодательства о недвижимом имуществе. Под общ. ред. В.В. Витрянского, О.М. Козырь, А.А. Маковской. М., 2004.

14. Мейер Д.И. Русское гражданское право. Ч. 2. М., 1997

15. Новицкая T.Е. Правовое регулирование имущественных отношений в России во второй половине XVIII века. M., 2005. 
DOI: 10.7256/1811-9018.2014.11.13092

При цитировании этой статьи сноска на dоі обязательна

\section{Право и политика $11(179) \cdot 2014$}

16. Патютко Д.Ю. Объекты незавершенного строительства как гражданско-правовая категория. // Дисс...канд. юрид. наук. М., 2011.

17. Пустовалова Е.А. Государственная регистрация прав на недвижимое имущество на современном этапе развития гражданского законодательства // // Автореф. дисс. . . канд. юрид. наук. .М. 2012.

18. Синицын С.А. Проблемы исковой защиты вещных прав на объекты недвижимости в гражданском праве России и правопорядках германского типа // Журнал зарубежного законодательства и сравнительного правоведения. - 2012. - 4. - С. $52-68$.

19. Тамазян С.К., Огурцова М.Н. Решение суда о признании незаконными действий регистрационных органов и его исполнение // Урбанистика и рынок недвижимости. - 2014. - 1. - C. 22-31. DOI: 10.7256/.2014.1.10178.

20. Субоч Е.Л. Правовая природа недвижимого имущества, его место в системе объектов гражданских прав // Урбанистика и рынок недвижимости. - 2014. - 1. - C. 12-21. DOI: 10.7256/.2014.1.10177.

21. В.А. Богоненко Правовое регулирование отношений в сфере недвижимости (на примере Швеции) // Журнал зарубежного законодательства и сравнительного правоведения. - 2011. - 3. - С. 69-74.

22. Кукушкин С.Н. Вопросы уголовно-правовой ответственности государственных регистраторов в сфере экономического оборота недвижимости (ст.170 и ст.285.3 УК РФ) // NB: Российское полицейское право. - 2013. - № 4. - C.45-60. DOI: 10.7256/2306-4218.2013.4.9251. URL: http://e-notabene.ru/pm/article_9251.html

23. Стерник Г.М., Стерник С.Г., Свиридов А.В.. Развитие и совершенствование методов прогнозирования на рынке жилой недвижимости // Урбанистика и рынок недвижимости. - 2014. - № 1. - С. 104-107. DOI: 10.7256/.2014.1.10025

24. Тадтаева В.В. Преимущества и недостатки планируемого налога на недвижимость // NB: Финансовое право и управление. - 2013. - № 2. - C.45-50. DOI: 10.7256/2306-4234.2013.2.742. URL: http://e-notabene.ru/flc/article 742.html

25. Миловидов О.Д.. Основные формы прав на недвижимость в законодательстве Великобритании и США // Урбанистика и рынок недвижимости. - 2014. - № 1. - С. 104-107. DOI: 10.7256/.2014.1.9776

26. Семизарова А.Г.. Проблематика учета объектов культурного наследия при подготовке документов территориального планирования муниципальных образований на примере Московской области // Урбанистика и рынок недвижимости. 2014. - № 1. - C. 104-107. DOI: 10.7256/.2014.1.10308

27. Тамазян С.К., Огурцова М.Н.. Решение суда о признании незаконными действий регистрационных органов и его исполнение // Урбанистика и рынок недвижимости. - 2014. - № 1. - C. 104-107. DOI: 10.7256/.2014.1.10178

28. Субоч Е.Л.. Правовая природа недвижимого имущества, его место в системе объектов гражданских прав // Урбанистика и рынок недвижимости. - 2014. - № 1. - C. 104-107. DOI: 10.7256/.2014.1.10177

29. Пылаева А.В.. О налоговой нагрузке на физических лиц по налогу на объекты жилого фонда, исчисленному на основе кадастровой стоимости // Налоги и налогообложение. - 2013. - № 7. - C. 104-107. DOI: 10.7256/1812-8688.2013.7.9345

30. Кукушкин С.Н.. Вопросы уголовно-правовой ответственности государственных регистраторов в сфере экономического оборота недвижимости (ст. 170 и ст. 285.3 УК РФ) // Полицейская деятельность. - 2012. - № 1. - С. 104-107

\section{References (transliterated):}

1. Alekseev V.A. Nedvizhimoe imushchestvo: pravovoi rezhim i gosudarstvennaya registratsiya prav // Diss. ... doktora yuridicheskikh nauk. M. 2008.

2. Babkin S.A. Osnovnye nachala organizatsii oborota nedvizhimosti. M., 2001.

3. Bazanov I.A. Proiskhozhdenie sovremennoi ipoteki. Noveishie techeniya v votchinnom prave v svyazi s sovremennym stroem narodnogo khozyaistva. M., 2004

4. Bevzenko R.S. Gosudarstvennaya registratsiya prav na nedvizhimoe imushchestvo: problemy i puti resheniya., M. 2011

5. Braginskii M.I., Vitryanskii V.V. Dogovornoe pravo. Kn. vtoraya: dogovory o peredache imushchestva. M., 2003

6. Demushkina E.S. Problemy primenimosti aktsessornosti i veshchnoi zashchity ipoteki v rossiiskom grazhdanskom prave. «Yurisprudentsiya», 2011.

7. Diskin E.I. Gosudarstvennaya registratsiya prav na nedvizhimoe imushchestvo na osnovanii sudebnykh aktov // Avtoref. diss. . . kand. yurid. nauk. .M. 2013.

8. Karibov K., Chaikovskaya O. Otmena gosudarstvennoi registratsii dogovorov arendy nedvizhimogo imushchestva // Sliyaniya i pogloshcheniya. № 3. 2013.

9. Kindeeva E.A., Piskunova M.G. Nedvizhimost': prava i sdelki. Kadastrovyi uchet i gosudarstvennaya registratsiya prav. M., 2011

10. Meier D.I. Russkoe grazhdanskoe pravo. Ch. 2. M., 1997

11. Novitskaya T.E. Pravovoe regulirovanie imushchestvennykh otnoshenii v Rossii vo vtoroi polovine XVIII veka. M., 2005.

12. Patyutko D.Yu. Ob" 'ekty nezavershennogo stroitel'stva kak grazhdansko-pravovaya kategoriya. // Diss...kand. yurid. nauk. M., 2011.

13. Pustovalova E.A. Gosudarstvennaya registratsiya prav na nedvizhimoe imushchestvo na sovremennom etape razvitiya grazhdanskogo zakonodatel'stva // // Avtoref. diss. . . kand. yurid. nauk. .M. 2012.

14. Sinitsyn S.A. Problemy iskovoi zashchity veshchnykh prav na ob'ekty nedvizhimosti v grazhdanskom prave Rossii i pravoporyadkakh germanskogo tipa // Zhurnal zarubezhnogo zakonodatel'stva i sravnitel'nogo pravovedeniya. - 2012. - 4. - C. 52-68.

15. Tamazyan S.K., Ogurtsova M.N. Reshenie suda o priznanii nezakonnymi deistvii registratsionnykh organov i ego ispolnenie // Urbanistika i rynok nedvizhimosti. - 2014. - 1. - C. 22-31. DOI: 10.7256/.2014.1.10178. 
DOI: $10.7256 / 1811-9018.2014 .11 .13092$

При цитировании этой статьи сноска на доі обязательна

Юридический практикум

16. Suboch E.L. Pravovaya priroda nedvizhimogo imushchestva, ego mesto v sisteme ob"'ektov grazhdanskikh prav // Urbanistika i rynok nedvizhimosti. - 2014. - 1. - C. 12-21. DOI: 10.7256/.2014.1.10177.

17. V.A. Bogonenko Pravovoe regulirovanie otnoshenii v sfere nedvizhimosti (na primere Shvetsii) // Zhurnal zarubezhnogo zakonodatel'stva i sravnitel'nogo pravovedeniya. - 2011. - 3. - C. 69-74.

18. Kukushkin S.N. Voprosy ugolovno-pravovoi otvetstvennosti gosudarstvennykh registratorov v sfere ekonomicheskogo oborota nedvizhimosti (st.170 i st.285.3 UK RF) // NB: Rossiiskoe politseiskoe pravo. - 2013. - № 4. - S.45-60. DOI: 10.7256/23064218.2013.4.9251. URL: http://e-notabene.ru/pm/article_9251.html

19. Sternik G.M., Sternik S.G., Sviridov A.V.. Razvitie i sovershenstvovanie metodov prognozirovaniya na rynke zhiloi nedvizhimosti // Urbanistika i rynok nedvizhimosti. - 2014. - № 1. - S. 104-107. DOI: 10.7256/.2014.1.10025

20. Tadtaeva V.V. Preimushchestva i nedostatki planiruemogo naloga na nedvizhimost' // NB: Finansovoe pravo i upravlenie. - 2013. - № 2. - S.45-50. DOI: 10.7256/2306-4234.2013.2.742. URL: http://e-notabene.ru/flc/article_742.html

21. Milovidov O.D.. Osnovnye formy prav na nedvizhimost' v zakonodatel'stve Velikobritanii i SShA // Urbanistika i rynok nedvizhimosti. - 2014. - № 1. - S. 104-107. DOI: 10.7256/.2014.1.9776

22. Semizarova A.G.. Problematika ucheta ob"'ektov kul'turnogo naslediya pri podgotovke dokumentov territorial'nogo planirovaniya munitsipal'nykh obrazovanii na primere Moskovskoi oblasti // Urbanistika i rynok nedvizhimosti. - 2014. - № 1. - S. 104-107. DOI: $10.7256 / .2014 .1 .10308$

23. Tamazyan S.K., Ogurtsova M.N.. Reshenie suda o priznanii nezakonnymi deistvii registratsionnykh organov i ego ispolnenie // Urbanistika i rynok nedvizhimosti. - 2014. - № 1. - S. 104-107. DOI: 10.7256/.2014.1.10178

24. Suboch E.L.. Pravovaya priroda nedvizhimogo imushchestva, ego mesto v sisteme ob"'ektov grazhdanskikh prav // Urbanistika i rynok nedvizhimosti. - 2014. - № 1. - S. 104-107. DOI: 10.7256/.2014.1.10177

25. Pylaeva A.V.. O nalogovoi nagruzke na fizicheskikh lits po nalogu na ob"ekty zhilogo fonda, ischislennomu na osnove kadastrovoi stoimosti // Nalogi i nalogooblozhenie. - 2013. - № 7. - S. 104-107. DOI: 10.7256/1812-8688.2013.7.9345

26. Kukushkin S.N.. Voprosy ugolovno-pravovoi otvetstvennosti gosudarstvennykh registratorov v sfere ekonomicheskogo oborota nedvizhimosti (st. 170 i st. 285.3 UK RF) // Politseiskaya deyatel'nost'. - 2012. - № 1. - S. 104-107 